\title{
Trends in bushmeat trade in a postconflict forest town: implications for food security
}

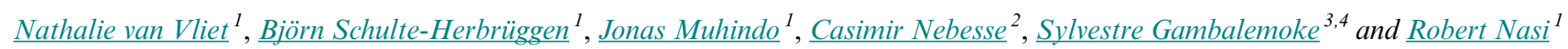

\begin{abstract}
Food insecurity and malnutrition can be major, yet often overlooked, consequences of armed conflicts because of the disruption of rural-urban trade networks and human migration toward safe urban centers. Bushmeat has been shown to act as an important safety net for conflict-affected urban populations, contributing the provisioning of basic needs and postconflict peace building efforts. However, the widely documented unsustainability of bushmeat hunting questions whether reliance of an urban population on bushmeat can be sustained for prolonged periods. To assess the potential contribution of bushmeat to sustainable food systems and peace building processes in a postconflict setting in the Democratic Republic of Congo, we use bushmeat trade data from the Kisangani market collected during three annual surveys in 2002, 2008/2009, and 2015/2016. Overall, we found a decreasing supply of bushmeat that, combined with an increasing human population size, limited the contribution of bushmeat to food security. Although bushmeat was the cheapest source of animal protein available in 2002, substitutes became more affordable over time, thereby reducing the need for bushmeat, especially among the urban poor. Finally, assessing the sustainability of bushmeat supply showed an ambiguous pattern depending on the indicator used, which may have been influenced by changes in the geographical trade routes, possibly mediating negative effects of local resource depletion on urban bushmeat supplies. This study provides insights into the contribution and the sustainability of bushmeat to urban postconflict food security. At the same time we also highlight the need for improved understanding of temporal supply/trade trajectories and especially the interaction between the sustainability of bushmeat harvest and the availability of affordable substitutes for ensuring sustainable food systems in support of peace building processes.
\end{abstract}

Key Words: bushmeat; Democratic Republic of Congo; food security; Kisangani; market; postconflict; sustainable food system; trade

\section{INTRODUCTION}

Food insecurity and malnutrition can be major, yet often overlooked, consequences of armed conflicts (Sogge 1994, Ramirez-Gomez et al. 2015, Taylor et al. 2015). Conflicts limit access to productive land in rural areas (Dudley et al. 2002, de Merode et al. 2004, Brncic et al. 2010, Lynch et al. 2013, Baptiste et al. 2017) and discourage farming and livestock production through direct attacks, terror, enslavement, forced recruitment, or land-mining. This results in long-lasting negative effects on food production and other economic activities (Cohen and Pinstrip-andersen 1999, Beall and Goodfelow 2014). Armed conflicts often trigger a rapid urban population growth because of the inflow of displaced rural populations creating challenges for the provisioning of basic needs such as health, food, and water supply (Kapagama and Waterhouse 2009, Maconachie et al. 2012, Lynch et al. 2013). Urban areas are also affected by the lack of free and safe movement of goods and people between rural and urban settings (Takamura 2015) disrupting preconflict trade networks and affecting food availability and price (Raleigh et al. 2015).

In conflict areas from central Africa, investment in agriculture and livestock production was limited, importation of food was minimal, and locally harvested bushmeat therefore played a major role in sustaining some level of food security as observed in Central African Republic (Fargeot 2010) and in Democratic Republic of Congo (de Merode and Cowlishaw 2006, van Vliet et al. 2012, Nackoney et al. 2014). Indeed, bushmeat is an easily available, affordable, and nutritious wild food (van Vliet et al. 2017) and can act as a safety net during periods of shortage or shock (Brown 2003, de Merode et al. 2004, Schulte-Herbrüggen et al. 2013) However, evidence of unsustainable hunting (Abernethy et al. 2016, Fa et al. 2016, Ripple et al. 2016) suggests a continued reliance on bushmeat in postconflict urban areas may not be sustainable, and hence endanger long-term food security and negatively affect human health through disease spillovers (Kurpiers et al. 2016), causing another burden for impoverished urban populations.

Because access to sufficient, nutritious, and healthy food for urban populations is a critical peace-building component to prevent new sources of postwar violence (Crush and Frayne 2011, Beall and Goodfelow 2014, Buhuag et al. 2015), serious investments to develop sustainable food systems are needed, either by supporting the recovery of the preconflict situation or by shaping new food systems able to meet the new patterns of demand. In Central African cities that have long depended on bushmeat as a predominant source of animal protein, postconflict reconfigurations should allow for a more diversified, safe, and sustainable food system, where other alternative sources of meat are made readily available and affordable for the poor.

In this paper we assess changes in the supply of bushmeat and other alternative proteins in a postconflict setting, using data from three annual surveys between 2002 and 2016. We assess the following: (1) changes in the supply of bushmeat; (2) trends in the affordability of bushmeat in comparison to alternative sources of animal protein; and (3) indicators of the sustainability of bushmeat supply. We use our results to infer policy recommendations for the management of this important, yet informal market chain and the development of a diversified sustainable food system.

${ }^{1}$ CIFOR (Center for International Forestry Research), ${ }^{2}$ Laboratoire d'Ecologie et de Gestion des Ressources Animales (LEGERA) Université de Kisangani, ${ }^{3}$ University of Kisangani, ${ }^{4}$ Institut Supérieur des Techniques Médicales d'Isiro 


\section{MATERIAL AND METHODS}

\section{Description of the study site}

Kisangani, the provincial capital of the Tshope Province and the third largest city in Democratic Republic of Congo (DRC), lies along the Congo River. Kisangani was an important development hub in the DRC national economy before the start of the war in the 1990s (Bavier 2008). Expatriate company-owned plantations produced various crops such as coffee, palm oil, rubber, and rice (Bezy et al. 1981), managed permanent stores that supplied industrial commodities, and maintained roads and bridges to facilitate the purchase and transportation of agricultural products from the peripheral rural villages (Takamura 2015). During the conflict, lasting from the early 1990s until the signing of a peace accord in 2003, Kisangani and the surrounding areas suffered from political unrest and fighting between Ugandan and Rwandan forces. The conflict resulted in an exodus of expatriates, leading to reduced economic activity, collapse of road infrastructure, and poverty in rural areas, mainly because villagers could no longer find markets for their cash crops (Kimura et al. 2015). The conflict officially ended in 2003 with the Lusaka Ceasefire Agreement, putting the surroundings of Kisangani in a seemingly state of peace and allowing the city to slowly reflourish as an influential trading center of agricultural products and imported merchandise, mediating between the DRC hinterland and neighboring Uganda (Takamura 2015). During the last 15 years, the urban population from Kisangani exploded from 247,000 inhabitants in 2002, to 628,000 in 2009 and 1,600,000 in 2015 (Institut National de la Statistique 2015).

In the Tshopo Province, agriculture and livestock production dramatically dropped during the conflict. Consequently, the population, both urban and rural, heavily relied on bushmeat as a main source of animal protein and income (de Merode et al. 2004, van Vliet et al. 2015a). In rural areas, bushmeat represented $9.6 \%$ of the total value of household production (de Merode et al. 2004) and bushmeat trade was the predominant way to earn cash (Kimura et al. 2015). At the same time, urban bushmeat markets flourished during the conflict. In Dungu, bushmeat sales massively increased during the armed conflict (de Merode and Cowlishaw 2006). Kisangani became a central market place for bushmeat, to feed the growing urban population (van Vliet et al. 2012). Up to the latest assessment available (van Vliet et al. $2015 a$, based on data collected in 2012), bushmeat and fish were still the most frequently consumed animal proteins in Kisangani, particularly among the poorer households (van Vliet et al. 2015a).

\section{Sampling design and data collection}

In Central African towns, local markets serve as the main point for the daily purchase of fresh food needed for household consumption (Chaléard 1996). Given their central role in food provision for urban households, markets are fundamental for understanding the supply and demand of food products. Market data can be used to understand the contribution of bushmeat to food security in terms of availability and prices by comparison with other sources of animal protein (fish, domestic animals, and caterpillars). In addition, trends on bushmeat trade derived from market data have been commonly used to assess the long-term sustainability of the supply (Juste et al. 1995, Brashares et al. 2004, Albrechtsen et al. 2005, Cowlishaw et al. 2005, Crookes et al. 2005, Wilkie et al. 2005, de Merode and Cowlishaw 2006, Fa et al. 2006, Brugiere and Magassouba 2009).

We focus our analysis on the sales occurring at the central market of Kisangani. We obtained prior permission from market authorities and the informed consent from the traders to collect data on the trade of bushmeat. We focused our study on mammal species, which commonly constitute the bulk of the bushmeat traded to urban areas (Fa et al. 2006, Nasi et al. 2011). The data collection focused on regular traders present on a daily basis and with whom we had established a relationship of trust. The first sampling period in 2002 corresponds to the end of five years of conflict (peace accords signed in 2003) and the market was visited every six to seven years thereafter. As such, we monitored the market over three different periods: January to December 2002, July 2008 to June 2009, and July 2015 to June 2016 (hereafter mentioned as 2002, 2009, and 2016, respectively). We visited the market approximately every three to six days resulting in a total sample of 313 trading days monitored. Our analysis of bushmeat supply to Kisangani offers conservative estimates for several reasons: (1) We considered only regular traders with whom we were able to establish trust relationships (occasional traders, generally a small number, were discarded to ensure data consistency); (2) We focused our study on the central market of Kisangani, assumed to distribute to other retailer markets in town. However, with urban growth many retailer markets may now be acting as wholesalers, especially those located on the main roads at the entrance of Kisangani. (3) We only took into account mammal species, but reptiles and amphibians also contribute as additional sources of meat.

Although the market is open the whole day, bushmeat arrives early in the morning and sales happen before noon. We recorded only carcasses reaching the market on the day of the visit. Each data record included species, number of carcasses, and transport routes along which the bushmeat was transported (Ituri, Ubundu, Lubutu, and others). In 2009 and 2016, we improved our data gathering protocol by also collecting information about the state of bushmeat (smoked, fresh, alive). Because of the difficulty of identifying certain taxa to the species level in smoked specimen these were recorded as generic groups, i.e., small diurnal monkeys, red duikers (Cephalophus natalensis), or bats.

To collect price data on a random basis covering each of the three sampling periods, we flipped a coin on each sampling day to determine whether prices were to be collected or not. When the head of the coin showed up, we assessed prices per kilogram of smoked meat (US\$/kg) of the most commonly sold mammal species in each group (rodents: brush-tailed porcupine Atherurus africanus, ungulates: blue duiker Philantomba monticola, and primates: small diurnal monkeys) and for the most commonly traded alternative protein sources (domestic animals commonly sold fresh: beef, goat, imported chicken, and pork; and other wild sources of meat: smoked or fresh caterpillars, fresh local fish) sold in different market stalls. In 2016, we also included prices for fresh local chicken.

Description of the indicators used in the analysis (Table 1): To analyze changes in supply, affordability, and long-term sustainability of bushmeat supply in Kisangani, we assessed (1) changes in bushmeat supply expressed in terms of daily and 
annual biomass traded and theoretical contribution to recommended meat intake; (2) changes in affordability of bushmeat species in comparison with other available sources of animal protein in the market; and (3) changes in a set of sustainability indicators.

Table 1. Criteria and indicators used in this study.

\begin{tabular}{|c|c|c|c|}
\hline $\begin{array}{l}\text { Criteria } \\
\text { Indicator }\end{array}$ & 2002 & 2009 & 2016 \\
\hline \multicolumn{4}{|l|}{ Supply } \\
\hline Daily biomass sold & $\mathrm{X}$ & $\mathrm{X}$ & $\mathrm{X}$ \\
\hline Annual biomass & $\mathrm{X}$ & $\mathrm{X}$ & $\mathrm{X}$ \\
\hline $\begin{array}{l}\text { Theoretical contribution of bushmeat to } \\
\text { recommended daily adult protein intake }\end{array}$ & $\mathrm{X}$ & $\mathrm{X}$ & $\mathrm{X}$ \\
\hline \multicolumn{4}{|c|}{$\begin{array}{l}\text { Affordability in comparison to other alternative sources of animal } \\
\text { protein }\end{array}$} \\
\hline $\begin{array}{l}\text { Price of bushmeat versus price of alternative } \\
\text { sources of animal protein }\end{array}$ & $\mathrm{X}$ & $\mathrm{X}$ & $\mathrm{X}$ \\
\hline $\begin{array}{l}\text { Price ratios of bushmeat versus other } \\
\text { alternatives }\end{array}$ & $\mathrm{X}$ & $\mathrm{X}$ & $\mathrm{X}$ \\
\hline \multicolumn{4}{|l|}{ Sustainability } \\
\hline $\begin{array}{l}\% \text { of biomass coming from critically } \\
\text { endangered }\end{array}$ & $\mathrm{X}$ & $\mathrm{X}$ & $\mathrm{X}$ \\
\hline$\%$ of biomass from totally protected species & $\mathrm{X}$ & $\mathrm{X}$ & $\mathrm{X}$ \\
\hline Species diversity index & $\mathrm{X}$ & $\mathrm{X}$ & $\mathrm{X}$ \\
\hline Game depletion index & $\mathrm{X}$ & $\mathrm{X}$ & $\mathrm{X}$ \\
\hline $\begin{array}{l}\text { Contribution of different taxonomic groups } \\
\text { to total daily biomass }\end{array}$ & $\mathrm{X}$ & $\mathrm{X}$ & $\mathrm{X}$ \\
\hline$\%$ of biomass coming from each trade route & $\mathrm{X}$ & $\mathrm{X}$ & $\mathrm{X}$ \\
\hline$\%$ of biomass sold fresh & & $\mathrm{X}$ & $\mathrm{X}$ \\
\hline
\end{tabular}

\section{Changes in supply}

Yearly and daily biomass: We calculated mean daily biomass traded (expressed as equivalent fresh weight in $\mathrm{kg}$ per sampling day) for each sampling period $\left(B_{\text {day }}\right)$. From this, the total annual bushmeat biomass sold $\left(\mathrm{B}_{\text {year }}\right)$ is

$$
\mathrm{B}_{\text {year }}=365 * \mathrm{~B}_{\text {day }}
$$

A decrease in mean daily biomass could either indicate a decrease in supply (because of depletion over the catchment areas [Fa et al. 2000, Crookes et al. 2005, Albrechtsen et al. 2007] or transportation constraints) or indicate a decrease in demand, for example, because of the competition with other sources of protein (Cowlishaw et al. 2005).

Theoretical contribution of bushmeat vis à vis the recommended meat allowance/adult/year: First, we calculated the bushmeat biomass available per adult per day $\left(\mathrm{B}_{\text {day/adult }}\right.$, in $\mathrm{kg} /$ adult/day) for each sampling period based on total human population data $\left(\mathrm{T}_{\text {pop }}\right.$ ) obtained from the official data (https://www.caid.cd/index. php/donnees-par-villes/ville-de-kisangani/?domaine=fiche ) and accounting for the proportion of adults in the population ( $44.1 \%$ according to Institut National de Statistic 2015).

$$
\mathrm{B}_{\text {day } / \text { adult }}=\mathrm{B}_{\text {day }} /\left(0.441 * \mathrm{~T}_{\text {pop }}\right)
$$

Then we calculated the theoretical contribution of bushmeat $\left(\mathrm{C}_{\mathrm{w}}\right)$ as the ratio of the annual biomass per adult compared to the recommended daily allowance (RDA) of meat, following $\mathrm{Fa}$ et al. 2003. We used an average RDA of $0.052 \mathrm{~kg} / \mathrm{adult} / \mathrm{day}$, following FAO/WHO 1985:

$$
\mathrm{C}_{\mathrm{w}}=\mathrm{B}_{\mathrm{day} / \mathrm{adult}} / \mathrm{RDA}
$$

A decrease in $\mathrm{C}_{\mathrm{w}}$ over time indicates that the supply of bushmeat relative to the adult human population, can theoretically contribute less for the RDA.

\section{Relative affordability}

Prices of wild terrestrial mammals in comparison with other available sources of animal protein in the market: To assess the relative affordability of bushmeat compared to alternative sources of animal protein, which is of particular importance to the urban poor, we compared prices per $\mathrm{kg}$ fresh meat of bushmeat with those of alternative sources of animal protein available in the market. For this we converted prices in US\$ of $\mathrm{kg}$ smoked meat to the equivalent weight in fresh meat, by applying a conversion factor (smoked meat/fresh meat) equal to 2.5 to obtain the price per $\mathrm{kg}$ of the equivalent weight of fresh meat (Fargeot 2013). As we focused on comparing prices within a survey period and only compared ratios across years, there was no need to correct prices for inflation. Price ratios for comparing the relative affordability of bushmeat compared to alternative sources of animal protein were calculated using sampling period means for each protein type. A decrease in the prices of alternative sources of animal protein relative to the price of bushmeat, would either indicate that bushmeat is becoming a luxury consumer good or that alternative proteins become available at more affordable prices (Cowlishaw et al. 2005, Fa et al. 2009).

Long-term sustainability

Contribution of critically endangered and fully protected species to the total biomass traded: To ascertain the likelihood for local depletion of vulnerable species in the future, we assessed the biomass contribution of critically endangered and fully protected species to the total biomass traded, based on IUCN red list and national laws, respectively (Ripple et al. 2016).

Game depletion index: A game depletion index (GDI) was calculated for each sampling period and compared across years (following $\mathrm{Fa}$ et al. 2015). For every species ${ }_{\mathrm{i}}$ ), we multiplied its rate of population increase $\left(\mathrm{r}_{\max }\right)$ by the number of carcasses $\left(\mathrm{n}_{i}\right)$ in each sampling period. We then added up the products computed for all species, and divided the sum by the total number of carcasses per sampling period traded in the market $(\mathrm{N})$ :

$$
\text { GDI: } \sum\left(r_{\max i} * n_{i}\right) / N
$$

where $r_{\operatorname{max~}}{ }^{*} n_{i}$ is derived for species $i$ in the market sample. The taxa specific value of $r_{\max }$ was calculated based on Caughley and Krebs (1983) formula

$$
\mathrm{r}_{\max }=1.5 * \mathrm{P}^{(-0.36)}
$$

with $\mathrm{P}=75 \%$ of adult weight based on Kingdon (2015). For species lumped into a group, e.g., small diurnal monkeys, we used a mean $r_{\text {max }}$ based the $r_{\max }$ value of each species potentially present in the group (based on the geographical distribution of each species). A higher GDI value indicated a more depleted supply area. 
Species diversity index: The species diversity index $(\mathrm{H})$ is equivalent to the Shannon diversity index and was calculated using the diversity function from the R Vegan package (Oksanen 2017):

$$
\mathrm{H}=\sum \mathrm{p}_{\mathrm{i}} * \ln \left(\mathrm{p}_{\mathrm{i}}\right)
$$

where $p_{i}$ is the proportion of species $i$.

For species lumped together, each group was treated as a single species. A decrease in species diversity could indicate that hunting is leading to the local depletion of the most vulnerable species, keeping only a few robust species in the landscape (Fa et al. 2015).

Contribution of different taxonomic groups to daily biomass: This indicator refers to the percentage of daily biomass composed by nonhuman primates, ungulates, and rodents. The three taxa differ strongly in vulnerability to hunting, predominantly because of differences in reproductive capacity, and a shift from vulnerable (nonhuman primates) to less vulnerable (ungulates) or least vulnerable (rodents) is commonly used to ascertain unsustainable harvest patterns (e.g., Cowlishaw et al. 2005, Dupain et al. 2012).

Percentage of biomass coming from each trade route: We examined the contribution of each trade route to the total biomass sold in Kisangani on a daily basis and observed changes over the 15-year period covered by the sampling. Changes in the contribution of each trade route may indicate that some source areas have become less profitable (because of depletion) and traders move to other areas to maintain supply.

Percentage of biomass sold fresh: We examined the proportion of total biomass sold fresh, as opposed to smoked or alive for 2009 and 2016. A decrease in the percentage of bushmeat sold fresh might indicate that hunters travel longer distances to access bushmeat (because of depletion nearby) and are therefore obliged to smoke the meat to ensure conservation.

\section{Data analysis}

All statistical analyses were conducted using $\mathrm{R}$ version 3.3.2 ( $\mathrm{R}$ Core Team 2014). To assess differences between sampling periods we used Generalized Linear Models (GLM) in the stats package version 3.3.2 with year (factor) as dependent variable. All data, unless otherwise stated were aggregated per sampling day, resulting in a total sample of 313 days. Continuous data were analyzed using Gaussian GLM with identity link, binary data were analyzed using binomial GLM with logit link function, percentage data was analyzed using quasi-binomial GLM with logit link, and count data were analyzed using Poisson GLM with $\log$ link. To allow the analysis of zero-inflated percentage data we conducted a two-step analysis, whereby we first analyzed differences in frequencies (binary) and then analyzed the scale of the response, i.e., only taking into account positive values. To assess differences between all combinations of sampling periods, we employed post-hoc tests (Tukey's HSD test) using the glht function in the multcomp package version 1.4-6.

\section{RESULTS}

\section{Changes in supply}

Mean daily biomass (equivalent fresh) across the three sampling periods equalled $1501 \mathrm{~kg} /$ day $(\mathrm{StDev}=1219)$. This resulted in an annual estimated amount of bushmeat sold of 643 tons in 2002,
830 tons in 2009, and 293 tons in 2016. Across sampling periods, mean daily biomass was significantly higher $(\mathrm{p}<0.001)$ in 2002 and 2009 than in 2016 with no significant difference observed between 2002 and 2009. The decrease in bushmeat sales over time combined with the human population growth, resulted in a decreased theoretical contribution of bushmeat to the recommended daily meat allowance over time, ranging from $32.4 \%$ of the adult RDA in 2002 , to $16.4 \%$ in 2009 , and to $2.2 \%$ in 2016 .

\section{Changes in relative affordability of bushmeat}

The comparison of price per $\mathrm{kg}$ ratios between bushmeat and alternative sources of animal protein showed that in 2002, alternatives cost about three-times as much as bushmeat (ratio = 0.31 ) and all (except caterpillars) were significantly more expensive than bushmeat species $(\mathrm{p}<0.001$ for all; Table 2$)$. Prices of alternatives decreased relative to bushmeat over time with a price ratio of 0.76 in 2009 and of 1.03 in 2016. Across different types of alternative animal protein sources, we found that they became relatively more affordable compared to bushmeat over time with pork becoming significantly cheaper than bushmeat ( $p$ $<0.05$ ) from 2009 and imported chicken becoming significantly cheaper than bushmeat in $2016(\mathrm{p}<0,001)$. Caterpillars cost less than bushmeat throughout the survey period. Also note that locally produced chicken was significantly more expensive than imported chicken in 2016 ( $p<0.001$ ). Hence in 2016, only local fish, locally produced chicken, beef, and goat were more expensive than bushmeat.

\section{Changes in sustainability indicators}

The indicators relating to the sustainability of bushmeat supply show a complex pattern (Table 3 ). Although biomass per sampling day decreased over the studied period, both species richness and game diversity index increased from 2002 to 2009 to 2016. However, while increases in species richness were all significant, game diversity only increased significantly from 2002 to 2009, suggesting that evenness in species abundance decreased toward 2016.

Changes in species richness and diversity were mirrored by the relative biomass contribution of different taxonomic groups on sale. Nonhuman primates, ungulates, and rodents composed $95 \%$ or more of the total biomass sold throughout the sampling periods. The top three species (or group of species) that contributed to the total biomass remained stable over time and concerned red duikers, bush pig, and small diurnal monkeys (Table 4). The relative contribution of ungulates decreased significantly from 2002 to 2009/2016, and that of primates increased during the same period. The contribution of rodents to the total biomass first increased and then decreased. The contribution of totally protected species and critically endangered species to the total biomass traded increased significantly over the 15-year period. Between 2009 and 2016, on days when fresh bushmeat was traded, it represented a significantly smaller proportion of total trade in 2016 than in 2009.

Finally, the biomass reaching the market through the different trade routes indicated a dynamic catchment area but showed no linear temporal trend in terms of the importance of each trade route (Table 5). Overall, Ituri and Lubutu were the most important trade routes and contributed bushmeat to the market on a nearly daily basis throughout the sampling periods. Lubutu trade 
Table 2. Mean prices for bushmeat and alternative animal protein sources (in US\$, showing mean and standard error) and the relative affordability of bushmeat compared with alternative animal protein sources. All ratios are expressed as mean price in US\$ per kg of equivalent fresh bushmeat and respective alternative source of animal protein

\begin{tabular}{lccc}
\hline \hline & 2002 & 2009 & 2016 \\
\hline Bushmeat & $2.56(\mathrm{SE}=0.09)$ & $2.60(\mathrm{SE}=0.07)$ & $4.72(\mathrm{SE}=0.13)$ \\
Atherurus africanus & $2.98(\mathrm{SE}=0.14)$ & $2.44(\mathrm{SE}=0.1)$ & $4.93(\mathrm{SE}=0.16)$ \\
Cercopithecus spp. & $2.20(\mathrm{SE}=0.16)$ & $2.77(\mathrm{SE}=0.13)$ & $4.4(\mathrm{SE}=0.24)$ \\
Philantomba monticola & $2.45(\mathrm{SE}=0.15)$ & $2.57(\mathrm{SE}=0.14)$ & $4.83(\mathrm{SE}=0.23)$ \\
& & & \\
Alternatives & $8.15(\mathrm{SE}=0.60)$ & $3.43(\mathrm{SE}=0.22)$ & $4.59(\mathrm{SE}=0.13)$ \\
beef & $13.9(\mathrm{SE}=0.17)$ & $6.07(\mathrm{SE}=0.05)$ & $5.56(\mathrm{SE}=0.04)$ \\
goat & $15.83(\mathrm{SE}=0.24)$ & $4.52(\mathrm{SE}=0.07)$ & $5.69(\mathrm{SE}=0.03)$ \\
pork & $3.28(\mathrm{SE}=0.11)$ & $1.13(\mathrm{SE}=0.02)$ & $4.16(\mathrm{SE}=0.02)$ \\
imported chicken & $10.26(\mathrm{SE}=0.16)$ & $3.59(\mathrm{SE}=0.03)$ & $3.46(\mathrm{SE}=0.04)$ \\
local chicken & $\mathrm{NA}$ & $\mathrm{NA}$ & $5.95(\mathrm{SE}=0.01)$ \\
local fish & $5.07(\mathrm{SE}=0.08)$ & $4.95(\mathrm{SE}=0.08)$ & $5.81(\mathrm{SE}=0.06)$ \\
caterpillar & $0.56(\mathrm{SE}=0.02)$ & $0.33(\mathrm{SE}=0.01)$ & $1.50(\mathrm{SE}=0.02)$ \\
& & & \\
Price ratio (bushmeat:alternatives) & 0.31 & 0.76 & 1.03 \\
Bushmeat:fresh beef & 0.18 & 0.43 & 0.85 \\
Bushmeat:fresh fish & 0.50 & 0.52 & 0.81 \\
Bushmeat:fresh local chicken & $\mathrm{NA}$ & $\mathrm{NA}$ & 0.79 \\
Bushmeat:imported chicken & 0.25 & 0.72 & 1.36 \\
Bushmeat:fresh pork & 4.57 & 2.29 & 1.13 \\
Bushmeat:fresh caterpillars & & & 3.85 \\
& & \\
\hline
\end{tabular}

Table 3. Summary statistics for sustainability indicators shown as mean per sampling day per period and the corresponding results of statistical analysis comparing means across combinations of sampling periods. $(--=$ not possible, $\mathrm{NS}=$ nonsignificant, $*=\mathrm{p}<0.05, * *=$ $\mathrm{p}<0.01, * * *=\mathrm{p}<0.001$.

\begin{tabular}{|c|c|c|c|c|c|c|}
\hline Variables & 2002 & 2009 & 2016 & $\begin{array}{c}2002 \\
\text { VS } \\
2009\end{array}$ & $\begin{array}{c}2002 \\
\text { vs } \\
2016\end{array}$ & $\begin{array}{c}2009 \\
\text { vs } \\
2016\end{array}$ \\
\hline Species richness & $7.78(\mathrm{SE}=0.16)$ & $9.27(\mathrm{SE}=0.43)$ & $11.13(\mathrm{SE}=0.17)$ & $* *$ & $* * *$ & $* * *$ \\
\hline Game diversity index & $0.51(\mathrm{SE}=0.02)$ & $0.77(\mathrm{SE}=0.03)$ & $0.84(\mathrm{SE}=0.02)$ & $* * *$ & $* * *$ & NS \\
\hline Game depletion index & 0.94 & 1.07 & 1.00 & -- & - & -- \\
\hline Proportion of NHP biomass & $0.17(\mathrm{SE}=0.01)$ & $0.22(\mathrm{SE}=0.02)$ & $0.21(\mathrm{SE}=0.01)$ & $*$ & NS & NS \\
\hline Proportion of Ungulate biomass & $0.80(\mathrm{SE}=0.01)$ & $0.67(\mathrm{SE}=0.02)$ & $0.69(\mathrm{SE}=0.01)$ & $* * *$ & $* * *$ & NS \\
\hline Proportion of Rodent biomass & $0.02(\mathrm{SE}=<0.01)$ & $0.10(\mathrm{SE}=0.01)$ & $0.05(\mathrm{SE}=<0.01)$ & $* * *$ & $* * *$ & $* * *$ \\
\hline \multirow[t]{2}{*}{$\%$ biomass - critically endangered } & $\begin{array}{l}\operatorname{Bin} 40.80 \% \\
(\mathrm{SE}=4.41 \%)\end{array}$ & $\begin{array}{c}\operatorname{Bin} 37.31 \% \\
(\mathrm{SE}=5.95 \%)\end{array}$ & $\begin{array}{c}\text { Bin } 57.85 \% \\
(\mathrm{SE}=4.51 \%)\end{array}$ & NS & $*$ & $*$ \\
\hline & $\begin{array}{l}\text { Scale } 0.54 \% \\
(\mathrm{SE}=0.22 \%)\end{array}$ & $\begin{array}{l}\text { Scale } 1.23 \% \\
(\mathrm{SE}=0.29 \%)\end{array}$ & $\begin{array}{l}\text { Scale } 4.41 \% \\
(\mathrm{SE}=0.54 \%)\end{array}$ & NS & $* * *$ & $* *$ \\
\hline$\%$ biomass - totally protected species & $7.13 \%(\mathrm{SE}=0.58 \%)$ & $13.71 \%(\mathrm{SE}=1.70 \%)$ & $19.49 \%(\mathrm{SE}=1.04 \%)$ & $* * *$ & $* * *$ & $* *$ \\
\hline$\%$ of biomass sold fresh & - & $\begin{array}{l}59.70 \%(\mathrm{SE}=6.04 \%) \\
4.96 \%(\mathrm{SE}=1.01 \%)\end{array}$ & $68.60 \%(\mathrm{SE}=4.24 \%)$ & - & - & $\begin{array}{l}\mathrm{NS} \\
* * *\end{array}$ \\
\hline
\end{tabular}

represented nearly half of all bushmeat traded in 2002, but contributed only $30 \%$ in 2009 and $20 \%$ in 2016 . In contrast, Ituri represented $39 \%$ of the biomass traded in 2002 and $73 \%$ in 2016.

\section{DISCUSSION}

Overall, we found a decreasing supply of bushmeat, which, combined with an increasing human population size, reduced the actual contribution of bushmeat to the recommended daily meat intake. Although bushmeat was the cheapest source of animal protein available in 2002, substitutes became more affordable over time, thereby reducing the reliance on bushmeat, especially among the poor. No clear indication of depletion was observed at the market level.

In 2016, a significant amount of bushmeat (293 tons) reached the central market of Kisangani, showing that bushmeat is still largely part of the menu in Kisangani. Despite these still high volumes of bushmeat recorded, our results show a significant decrease of bushmeat supplied to the central market of Kisangani over the last 15 years. This trend may also be exacerbated by the emergence of new wholesale markets having flourished at the periphery of the town. The combined effect of the decreased supply in 
Table 4. Biomass recorded for each species (or group of species) in each of the sampling periods, expressed as equivalent of fresh meat $(\mathrm{kg})$. Bold values indicate the top five species contributing to the overall biomass per sampling year.

\begin{tabular}{|c|c|c|c|}
\hline \multirow[b]{2}{*}{ Species or group of species } & \multicolumn{3}{|c|}{ biomass in $\mathrm{kg}$ (equivalent fresh) } \\
\hline & 2002 & 2009 & 2016 \\
\hline Philantomba monticola & 11,154 & 14,561 & 3618 \\
\hline Pan troglodytes & 4545 & 1877 & 4074 \\
\hline Potamochoerus porcus & 51,102 & 25,051 & 25,247 \\
\hline Red duikers $^{\dagger}$ & 80,050 & 31,769 & 18,044 \\
\hline Small monkeys & 36,006 & 30,978 & 9382 \\
\hline Cephalophus silvicultor & 5580 & 5820 & 5520 \\
\hline Atherurus africanus & 3310 & 7314 & 2147 \\
\hline Hyemoschus aquaticus & 9,790 & 13,685 & 8953 \\
\hline Syncerus cafer & 4085 & 3029 & 4132 \\
\hline Loxodonta africana & 903 & 640 & 731 \\
\hline Manis gigantea & 224 & 939 & 2902 \\
\hline Manis tricuspis & 9 & 0 & 0 \\
\hline Okapia johnstoni & 0 & 661 & 1389 \\
\hline Orycteropus afer & 601 & 438 & 495 \\
\hline Pan paniscus & 0.0 & 835 & \\
\hline Papio anubis & 103 & 856 & 6388 \\
\hline Thryonomys swinderianus & 35 & 91 & 1406 \\
\hline Tragelaphus spekei & 12,437 & 7395 & 1197 \\
\hline Phataginus tetradactyla & 0 & 0 & 136 \\
\hline Bats & 372 & 38 & 131 \\
\hline Bdeogale nigripes & 20 & & \\
\hline Cricetomys emini & 0 & 6534 & 1319 \\
\hline Crossarchus alexandri & 1 & 27 & \\
\hline Geneta spp. & 0 & 0 & 12 \\
\hline TOTAL biomass & 220,327 & 152,539 & 97,221 \\
\hline sampling days per sampling year & $\mathrm{N}=125$ & $\mathrm{~N}=67$ & $\mathrm{~N}=121$ \\
\hline
\end{tabular}

${ }^{\dagger}$ Several red duiker species (Cephalophus callipygus, Cephalophus dorsalis, etc.) are lumped into one group because carcasses were not always identified to species level at the market.

Table 5. Percentage of total biomass entering the Kisangani market along different trade routes showing the percentage of sampling days bushmeat was recorded arriving from each trade route (frequency) and the total daily biomass recorded per route on days when trade on a route was recorded (scale). $(--=$ not applicable, NS $=$ nonsignificant, $*=p<0.05, * *=p<0.01, * * *=p<0.001)$

\begin{tabular}{|c|c|c|c|c|c|c|c|}
\hline Variables & & 2002 & 2009 & 2016 & $\begin{array}{c}2002 \\
\text { vs } \\
2009\end{array}$ & $\begin{array}{c}2002 \\
\text { vs } \\
2016 \\
\end{array}$ & $\begin{array}{c}2009 \\
\text { vs } \\
2016\end{array}$ \\
\hline \multirow[t]{3}{*}{$\%$ biomass - Ituri } & Mean & 0.39 & 0.70 & 0.73 & -- & -- & -- \\
\hline & Frequency & $99.20(\mathrm{SE}=0.80)$ & $100(\mathrm{SE}=0)$ & $100(\mathrm{SE}=0)$ & NS & NS & NS \\
\hline & Scale & $38.93(\mathrm{SE}=1.74)$ & $69.89(\mathrm{SE}=2.24)$ & $72.94(\mathrm{SE}=1.47)$ & $* * *$ & $* * *$ & NS \\
\hline \multirow[t]{3}{*}{$\%$ biomass - Lubutu } & Mean & 0.49 & 0.28 & 0.19 & - & - & -- \\
\hline & Frequency & $\operatorname{Bin} 100(\mathrm{SE}=0)$ & $\operatorname{Bin} 92.42(\mathrm{SE}=3.28)$ & $\operatorname{Bin} 93.39(\mathrm{SE}=2.27)$ & NS & NS & NS \\
\hline & Scale & $48.72(\mathrm{SE}=1.73)$ & $30.59(\mathrm{SE}=2.04)$ & $20.26(\mathrm{SE}=1.11)$ & $* * *$ & $* * *$ & $* * *$ \\
\hline \multirow[t]{3}{*}{$\%$ biomass - Ubundu } & Mean & 0.09 & 0.02 & 0.07 & - & - & -- \\
\hline & Frequency & $84.00(\mathrm{SE}=3.29)$ & $21.21(\mathrm{SE}=5.00)$ & $68.60(\mathrm{SE}=4.24)$ & $* * *$ & $*$ & $* * *$ \\
\hline & Scale & $10.72(\mathrm{SE}=1.11)$ & $7.08(\mathrm{SE}=1.62)$ & $10.50(\mathrm{SE}=0.84)$ & $* * *$ & $* * *$ & $* * *$ \\
\hline \multirow[t]{3}{*}{$\%$ biomass - Other } & Mean & 0.04 & $<0.01$ & $<0.01$ & - & - & -- \\
\hline & Frequency & $40.00(\mathrm{SE}=4.40)$ & $6.06(\mathrm{SE}=2.96)$ & $22.31(\mathrm{SE}=3.80)$ & -- & $*$ & -- \\
\hline & Scale & $9.15(\mathrm{SE}=1.01)$ & $5.57(\mathrm{SE}=1.80)$ & $4.22(\mathrm{SE}=0.68)$ & -- & $* * *$ & -- \\
\hline
\end{tabular}

bushmeat and the increased human population reduces the contribution of bushmeat to the RDA. Unless other alternative proteins actually become substitutes to bushmeat, this may imply consumption levels of meat far below the recommended daily intake. Nevertheless, it is important to keep in mind that market volumes, as measured in this study, are only an underestimation of bushmeat consumption given that nonmarket transactions (gifts) are also common and could also potentially constitute a safety net for food security in times of conflict as observed in Ghana for a variety of forest resources (Boafo et al. 2016).

Although our study does not quantify the availability of other sources of meat, it shows that price wise, some domestic sources 
of meat have become competitive substitutes to bushmeat over the 15-year period. Although in 2002, only caterpillars (a highly seasonal food item) could compete with bushmeat, in 2016, imported chicken and pork became competitive with bushmeat offering access to a higher diversity of animal proteins to urban households. All locally produced animal proteins except caterpillars (fish, bushmeat, chicken) were significantly more expensive than the cheapest source of animal protein (imported chicken) in 2016, indicating that urban households are increasingly dependent on imported sources of animal protein, as already shown in other tropical forest areas (Nardoto et al. 2011, van Vliet et al. 2015b). The increased competition of alternative sources of animal protein could imply substitution to bushmeat. However, poverty levels may be so high that many households cannot afford any type of protein at all. Based on interviews with children at school, van Vliet et al. (2015a) showed that $44 \%$ of the children in Kisangani had not consumed any type of animal protein the day before the interview.

As opposed to other bushmeat market trend studies available for tropical forests in Africa portraying depletion or postdepletion scenarios (Cowlishaw et al. 2005, Crookes et al. 2005), our analysis shows an ambiguous picture of the sustainability of bushmeat supply and hence its potential long-term contribution to future food security. We observed a decrease in daily biomass, the increase in rodent's contribution to total biomass, the decrease in fresh bushmeat as compared to smoked bushmeat. However, we did not detect a consistent trend in game depletion index. We saw an increase in species diversity and the persistence of ungulates representing the bulk of the trade. We also recorded an increased availability of critically endangered and totally protected species, which either indicates that hunters are entering relatively undisturbed areas, e.g., poaching in protected areas, or that hunting patterns allow for those vulnerable species to be maintained over time (at least in part of the catchment). However, local depletion patterns could become invisible at the market level if new trade routes are able to continue to supply the market, even when other areas are being locally depleted. At the same time, the deterioration of some supply roads could reduce hunting pressure there and allow these areas to recover before they serve again to supply the market (when roads are improved again). As such, a process similar to the shifting cultivation/fallow system may be helping to maintain sustainability over time through complex source-sink dynamics (Novaro et al. 2000, van Vliet et al. 2010, Mockrin 2011).

Our results contribute to a better understanding of the supply of bushmeat and its affordability for urban dwellers in comparison to other sources of animal protein. A quantitative assessment of the current overall supply of animal sources of protein to Kisangani is urgently required to measure the amount of meat needed to guarantee adequate levels of protein intake for the population. This quantitative assessment should be sensitive to variations in household income levels to ensure that not only sufficient quantities are available but also that these are available to all parts of society. Moreover, nutritional qualities of animal protein sources vary widely and nutrition surveys should be conducted to assess the current level of food insecurity and infer qualitative recommendations concerning the quality of meats that need to be made available. Ensuring access to fresh and healthy food and a rapid market supply essentially means increased access to locally produced animal proteins (De Zeeuwet al. 2011, Kwenbe et al. 2016). However, without the necessary technical and capacity building support, it is more likely that cheap, low quality foods, e.g., imported industrial chicken, will become the only protein accessible to the poor.

\section{CONCLUSION}

In Kisangani, food security has largely relied on the resilience of natural ecosystems as providers of wild sources of food. However, given the new challenges posed by human population growth, Kisangani clearly requires a diversification of affordable animal sources of protein to guarantee the resilience of the food system in the future. For this, we recommend the following three pillars of intervention: (1) manage the bushmeat (and fish) trade chains for sustainability; (2) develop an enabling institutional environment (both private and public) for the development of sustainable and contextually relevant domestic meat production systems to ensure a diversity of locally produced, healthy foods; (3) invest in transportation means (roads, air, or river traffic, etc.) to connect Kisangani to larger production areas to support increased access to exported sources of animal protein.

Responses to this article can be read online at: http://www.ecologyandsociety.org/issues/responses. php/9780

\section{Acknowledgments:}

This work was carried out as part of Bushmeat research Initiative within the CGIAR research programme on Forests, Trees and Agroforestry. We are grateful for the contribution and trust of the traders at the central market of Kisangani and the support from the University of Kisangani.This work would not have been possible without the financial support from the European Union through the FCCC project and USAID.

\section{LITERATURE CITED}

Abernethy, K., F. Maisels, and L. J. White. 2016. Environmental issues in Central Africa. Annual Review of Environment and Resources 41(1):1-33. http://dx.doi.org/10.1146/annurevenviron-110615-085415

Albrechtsen, L., J. E. Fa, B. Barry, and D. W. Macdonald. 2005. Contrasts in availability and consumption of animal protein in Bioko Island, West Africa: the role of bushmeat. Environmental Conservation 32(4):340-348. http://dx. doi.org/10.1017/ S0376892906002694

Albrechtsen, L., D. W. Macdonald, P. J. Johnson, R. Castelo, and J. E. Fa. 2007. Faunal loss from bushmeat hunting: empirical evidence and policy implications in Bioko Island. Environmental Science \& Policy 10(7-8):654-667. http://dx.doi.org/10.1016/j. envsci.2007.04.007

Baptiste, B., M. Pinedo-Vasquez, V. H. Gutierrez-Velez, G. I. Andrade, P. Vieira, L. M. Estupiñán-Suárez, M. C. Londoño, W. Laurance, and T. M. Lee. 2017. Greening peace in Colombia. Nature Ecology \& Evolution 1:0102. http://dx.doi.org/10.1038/ s41559-017-0102 
Bavier, J. 2008. Congo war-driven crisis kills 45,000 a month: study. Reuters, 22 January. [online] URL: https://www.reuters. com/article/us-congo-democratic-death/congo-war-driven-crisiskills-45000-a-month-study-idUSL2280201220080122

Beall, J., and T. Goodfellow. 2014. Conflict and post-war transition in African cities. Pages 18-34 in S. Parnell and E. Pieterse, editors. Africa's urban revolution. Zed, London, UK.

Bezy, F., J. Peeman, and J. Wautelet. 1981. Accumulation et sousdévelopement au Zaire, 1960-1980. Press Universitaire de Louvain, Louvain-la-Nueve, Belgium.

Brashares, J. S., P. Arcese, M. K. Sam, P. B. Coppolillo, A. R. E. Sinclair, and A. Balmford. 2004. Bushmeat hunting, wildlife declines, and fish supply in West Africa. Science 306 (5699):1180-1183. http://dx.doi.org/10.1126/science.1102425

Brncic, T. M., B. Amarasekaran, and A. McKenna. 2010. Sierra Leone national chimpanzee census. Tacugama Chimpanzee Sanctuary, Freetown, Sierra Leone.

Brown, D. 2003. Bushmeat \& poverty alleviation: implications for development policy. Wildlife Policy Briefing No. 2. ODI, London, UK. https://www.odi.org/sites/odi.org.uk/files/odi-assets/publicationsopinion-files/3308.pdf

Brugiere, D., and B. Magassouba. 2009. Pattern and sustainability of the bushmeat trade in the Haut Niger National Park, Republic of Guinea. African Journal of Ecology 47(4):630-639. http://dx. doi.org/10.1111/j.1365-2028.2008.01013.x

Boafo, Y. A., O. Saito, G. S. Jasaw, K. Otsuki, and K. Takeuchi. 2016. Provisioning ecosystem services-sharing as a coping and adaptation strategy among rural communities in Ghana's semiarid ecosystem. Ecosystem Services 19:92-102. http://dx.doi. org/10.1016/j.ecoser.2016.05.002

Buhaug, H., T. A. Benjaminsen, E. Sjaastad, and O. M. Theisen. 2015. Climate variability, food production shocks, and violent conflict in Sub-Saharan Africa. Environmental Research Letters 10(12):125015. http://dx.doi.org/10.1088/1748-9326/10/12/125015

Caughley, G., and C. J. Krebs. 1983. Are big mammals simply little mammals writ large? Oecologica 59(1):7-17. http://dx.doi. org/10.1007/BF00388066

Chaléard, J. L. 1996. Les mutations de l'agriculture commerciale en Afrique de l'Ouest. Annales de Géographie 105(592):563-583. http://dx.doi.org/10.3406/geo.1996.20753

Cohen, M. J., and P. Pinstrup-Andersen. 1999. Food security and conflict. Social Research 66(1):375-416.

Cowlishaw, G., S. Mendelson, and J. M. Rowcliffe. 2005. Evidence for post-depletion sustainability in a mature bushmeat market. Journal of Applied Ecology 42(3):460-468. http://dx.doi. org/10.1111/j.1365-2664.2005.01046.X

Crookes, D. J., N. Ankudey, and E. J. Milner-Gulland. 2005. The value of a long-term bushmeat market dataset as an indicator of system dynamics. Environmental Conservation 32(04):333-339. http://dx.doi.org/10.1017/S037689290500250X

Crush, J. S., and G. B. Frayne. 2011. Urban food insecurity and the new international food security agenda. Development Southern Africa 28(4):527-544. http://dx.doi.org/10.1080/03768$\underline{35 X .2011 .605571}$
De Merode, E., and G. Cowlishaw. 2006. Species protection, the changing informal economy, and the politics of access to the bushmeat trade in the Democratic Republic of Congo. Conservation Biology 20(4):1262-1271. http://dx.doi.org/10.1111/ j.1523-1739.2006.00425.x

De Merode, E., K. Homewood, and G. Cowlishaw. 2004. The value of bushmeat and other wild foods to rural households living in extreme poverty in Democratic Republic of Congo. Biological Conservation 118(5):573-581. http://dx.doi.org/10.1016/j. biocon.2003.10.005

De Zeeuw, H., R. Van Veenhuizen, and M. Dubbeling. 2011. The role of urban agriculture in building resilient cities in developing countries. Journal of Agricultural Science 149(S1):153-163. http:// dx.doi.org/10.1017/S0021859610001279

Dudley, J. P., J. R. Ginsberg, A. J. Plumptre, J. A. Hart, and L. C. Campos. 2002. Effects of war and civil strife on wildlife and wildlife habitats. Conservation Biology 16(2):319-329. http://dx. doi.org/10.1046/j.1523-1739.2002.00306.x

Dupain, J., J. Nackoney, J. M. Vargas, P. J. Johnson, M. A. Farfán, M. Bofaso, and J. E. Fa. 2012. Bushmeat characteristics vary with catchment conditions in a Congo market. Biological Conservation 146(1):32-40. http://dx.doi.org/10.1016/j.biocon.2011.11.025

Fa, J. E., L. Albrechtsen, P. J. Johnson, and D. W. Macdonald. 2009. Linkages between household wealth, bushmeat and other animal protein consumption are not invariant: evidence from Rio Muni, Equatorial Guinea. Animal Conservation 12(6):599-610. http://dx.doi.org/10.1111/j.1469-1795.2009.00289.x

Fa, J. E., D. Currie, and J. Meeuwig. 2003. Bushmeat and food security in the Congo Basin: linkages between wildlife and people's future. Environmental Conservation 30(1):71-78. http:// dx.doi.org/10.1017/S0376892903000067

Fa, J. E., J. Olivero, M. Á. Farfán, A. L. Márquez, J. Duarte, J. Nackoney, A. Hall, J. Dupain, S. Seymour, P. J. Johnson, D. W. Macdonald, R. Real, and J. M. Vargas. 2015. Correlates of bushmeat in markets and depletion of wildlife. Conservation Biology 29(3):805-815. http://dx.doi.org/10.1111/cobi.12441

Fa, J. E., S. Seymour, J. Dupain, R. Amin, L. Albrechtsen, and D. Macdonald. 2006. Getting to grips with the magnitude of exploitation: bushmeat in the Cross-Sanaga rivers region, Nigeria and Cameroon. Biological Conservation 129(4):497-510. http:// dx.doi.org/10.1016/j.biocon.2005.11.031

Fa, J. E., N. van Vliet, and R. Nasi. 2016. Bushmeat, food security, and conservation in African rainforests. Pages 331-344 in A. A. Aguirre and R. Sukumar, editors. Tropical conservation: perspectives on local and global priorities. Oxford University Press, Oxford, UK.

Fa, J. E., J. E. G. Yuste, and R. Castelo. 2000. Bushmeat markets on Bioko Island as a measure of hunting pressure. Conservation Biology 14(6):1602-1613. http://dx.doi.org/10.1111/j.1523-1739.2000.99067. $\underline{\mathrm{x}}$

Fargeot, C. 2010. Bushmeat consumption in Central African Republic. XXIII IUFRO Congress, 23-28 August. Seoul, South Korea.

Fargeot, C. 2013. La chasse commerciale en Afrique centrale: une menace pour la biodiversité ou une activité économique durable?: le 
cas de la république centrafricaine. Université Paul ValéryMontpellier III, Montpellier, France.

Food and Agriculture Organization and World Health Organization (FAO/WHO). 1985. Energy and protein requirements. WHO Technical Report Series 724. WHO, Geneva, Switzerland.

Institut National de la Statistique. 2015. Annuaire Statistique 2014. Institut National de la Statistique, Kinshasa, République Démocratique du Congo.

Juste, J., J. E. Fa, J. P. Del Val, and J. Castroviejo. 1995. Market dynamics of bushmeat species in Equatorial Guinea. Journal of Applied Ecology 32(3):454-467. http://dx.doi.org/10.2307/2404644

Kapagama, P., and R. Waterhouse. 2009. Portrait of Kinshasa: a city on (the) edge. Working Paper No. 53 (series 2). Crisis States Research Centre, Department for International Development, London, UK.

Kimura, D., H. Masuda, and R. Yamaguchi. 2015. Change in land use among the Bongando in the Democratic Republic of the Congo. African Study Monographs S1:5-35.

Kingdon, J. 2015. The Kingdon field guide to African mammals. Bloomsbury, London, UK.

Kurpiers, L. A., B. Schulte-Herbrüggen, I. Ejotre, and D. M. Reeder. 2016. Bushmeat and emerging infectious diseases: lessons from Africa. Pages 507-551 in F. M. Angelici, editor. Problematic wildlife. Springer, Cham, Switzerland. http://dx.doi. org/10.1007/978-3-319-22246-2 24

Kwembe, J. T. K., J. P. Mbula, J. Tchatchambe, M. T. Bokota, and P. T. Mpiana. 2016. Evolution avec le temps de la qualité organoleptique et physico-chimique des oeufs de poule vendus à Kisangani (RD Congo)/[Evolution with time of organoleptic and physicochemical qualities of hen eggs sold at Kisangani (DR Congo)]. International Journal of Innovation and Applied Studies 14(4):1036-1047.

Lynch, K., R. Maconachie, T. Binns, P. Tengbe, and K. Bangura. 2013. Meeting the urban challenge? Urban agriculture and food security in post-conflict Freetown, Sierra Leone. Applied Geography 36:31-39. http://dx.doi.org/10.1016/j.apgeog.2012.06.007

Maconachie, R., T. Binns, and P. Tengbe. 2012. Urban farming associations, youth and food security in post-war Freetown, Sierra Leone. Cities 29(3):192-200. http://dx.doi.org/10.1016/j.cities.2011.09.001

Mockrin, M. H., R. F. Rockwell, K. H. Redford, and N. S. Keuler. 2011. Effects of landscape features on the distribution and sustainability of ungulate hunting in northern Congo. Conservation Biology 25(3):514-525. http://dx.doi.org/10.1111/ j.1523-1739.2011.01660.x

Nackoney, J., G. Molinario, P. Potapov, S. Turubanova, M. C. Hansen, and T. Furuichi. 2014. Impacts of civil conflict on primary forest habitat in northern Democratic Republic of the Congo, 1990-2010. Biological Conservation 170:321-328. http:// dx.doi.org/10.1016/j.biocon.2013.12.033

Nardoto, G. B., R. S. S Murrieta, L. E. G. Prates, C. Adams, M. E. P. E. Garavello, T. Schor, A. De Moraes, F. D. Rinaldi, J. G. Gragnani, E. A. F. Moura, P. J. Duarte-Neto, and L. A. Martinelli.
2011. Frozen chicken for wild fish: nutritional transition in the Brazilian Amazon region determined by carbon and nitrogen stable isotope ratios in fingernails. American Journal of Human Biology 23(5):642-650. http://dx.doi.org/10.1002/ajhb.21192

Nasi, R., A. Taber, and N. van Vliet. 2011. Empty forests, empty stomachs? Bushmeat and livelihoods in the Congo and Amazon Basins. International Forestry Review 13(3):355-368. http://dx.doi. org/10.1505/146554811798293872

Novaro, A. J., K. H. Redford, and R. E. Bodmer. 2000. Effect of hunting in source-sink systems in the neotropics. Conservation Biology 14(3):713-721. http://dx.doi.org/10.1046/j.1523-1739.2000.98452. $\underline{x}$

Oksanen, J., F. G. Blanchet, M. Friendly, Roeland Kindt, P. Legendre, D. McGlinn, P. R. Minchin, R. B. O'Hara, G. L. Simpson, P. Solymos, M. H. H. Stevens, Ed. Szoecs, and H. Wagner. 2017. R Package 'vegan'. [online] URL: https://cran.rproject.org/web/packages/vegan/vegan.pdf

R Core Team. 2014. R: A language and environment for statistical computing. R Foundation for Statistical Computing, Vienna, Austria. [online] URL: http://www.R-project.org/

Raleigh, C., H. J. Choi, and D. Kniveton. 2015. The devil is in the details: an investigation of the relationships between conflict, food price and climate across Africa. Global Environmental Change 32:187-199. http://dx.doi.org/10.1016/j.gloenvcha.2015.03.005

Ramirez-Gomez, S. O. I., C. A. Torres-Vitolas, K. Schreckenberg, M. Honzák, G. S. Cruz-Garcia, S. Willcock, E. Palacios, E. PérezMiñana, P. A. Verweij, and G. M. Poppy. 2015. Analysis of ecosystem services provision in the Colombian Amazon using participatory research and mapping techniques. Ecosystem Services 13:93-107. http://dx.doi.org/10.1016/j.ecoser.2014.12.009

Ripple, W. J., K. Abernethy, M. G. Betts, G. Chapron, R. Dirzo, M. Galetti, T. Levi, P. A. Lindsey, D. W. Macdonald, B. Machovina, T. M. Newsome, C. A. Peres, A. D. Wallach, C. Wolf, and H. Young. 2016. Bushmeat hunting and extinction risk to the world's mammals. Royal Society Open Science 3(10):160498. http://dx.doi.org/10.1098/rsos. 160498

Schulte-Herbrüggen, B., G. Cowlishaw, K. Homewood, and J. M. Rowcliffe. 2013. The importance of bushmeat in the livelihoods of West African cash-crop farmers living in a faunally-depleted landscape. PLoS ONE 8(8):e72807. http://dx.doi.org/10.1371/ journal.pone.0072807

Sogge, D. 1994. Angola: surviving against rollback and petrodollars. Pages 92-110 in J. Macrae and A. Zwi, editors. War and hunger: rethinking international responses to complex emergencies. Zed, London, UK.

Takamura, S. 2015. Reorganizing the distribution system in postconflict society: a study on orientale province, the Democratic Republic of the Congo. African Study Monographs S51:77-91.

Taylor, G., J. P. W. Scharlemann, M. Rowcliffe, N. Kümpel, M. B. J. Harfoot, J. E. Fa, R. Melisch, E. J. Milner-Gulland, S. Bhagwat, K. A Abernethy, et al. 2015. Synthesising bushmeat research effort in West and Central Africa: a new regional database. Biological Conservation 181:199-205. http://dx.doi.org/10.1016/j.biocon.2014.11.001 
van Vliet, N., J. E. Fa, and R. Nasi. 2015b. Managing hunting under uncertainty: from one-off ecological indicators to resilience approaches in assessing the sustainability of bushmeat hunting. Ecology and Society 20(3):7. http://dx.doi.org/10.5751/ES-07669-200307

van Vliet, N., E. J. Milner-Gulland, F. Bousquet, M. Saqalli, and R. Nasi. 2010. Effect of small-scale heterogeneity of prey and hunter distributions on the sustainability of bushmeat hunting. Conservation Biology 24(5):1327-1337. http://dx.doi.org/10.1111/ j.1523-1739.2010.01484.X

van Vliet, N., J. Moreno, J. Gomez, W. Zhou, J. E. Fa, C. Golden, R. R. Nobrega Alves, and R. Nasi. 2017. Bushmeat and human health: assessing the evidence in tropical and sub-tropical forests. Ethnobiology and Conservation 6.

van Vliet, N., C. Nebesse, S. Gambalemoke, D. Akaibe, and R. Nasi. 2012. The bushmeat market in Kisangani, Democratic Republic of Congo: implications for conservation and food security. Oryx 46(02):196-203. http://dx.doi.org/10.1017/

$\underline{\mathrm{S} 0030605311000202}$

van Vliet, N., C. Nebesse, and R. Nasi. 2015a. Bushmeat consumption among rural and urban children from Province Orientale, Democratic Republic of Congo. Oryx 49(01):165-174. http://dx.doi.org/10.1017/S0030605313000549

Wilkie, D. S., M. Starkey, K. Abernethy, E. N. Effa, P. Telfer, and R. Godoy. 2005. Role of prices and wealth in consumer demand for bushmeat in Gabon, Central Africa. Conservation Biology 19 (1):268-274. http://dx.doi.org/10.1111/j.1523-1739.2005.00372.x 